Convenience store location planning and forecasting - a practical research agenda

\section{Steve Wood}

School of Management, University of Surrey

\section{Sue Browne}

The ORC Partnership

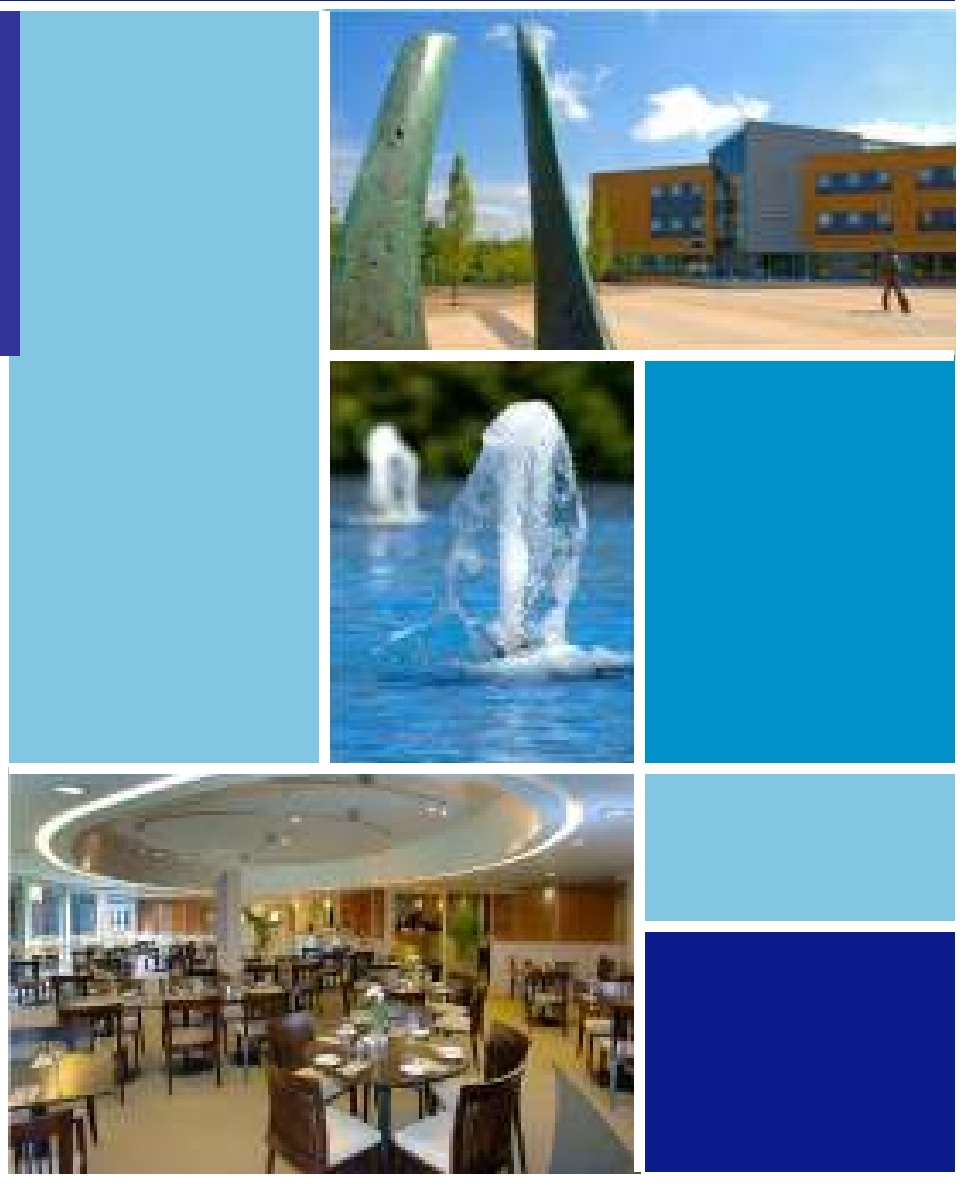

Unis

University of Surrey School of Management 


\section{Background}

- The site selection \& sales forecasting literature is extensive

- Predominantly focused on the food supermarket

- Why?

- Principal format through which food is sold $(74 \%)$

- Huge sunk cost implications of the decision

- Dependent on regular expenditure 


\section{Background (cont)}

- Lack of attention to convenience store forecasting. Partly due to:

- lower sunk cost implications;

- lack of capital invested by operators in sophisticated forecasting approaches;

- the less habitual nature of purchases;

- difficult to forecast sales 


\section{Background (cont)}

- So less sophisticated approaches predominate with smaller retailers:

- 'Location planning is often undertaken on the basis of subjective rules of thumb and a degree of opportunism relating to the availability of individual sites' (Pioch and Byrom, 2004, 223)

- By 'intuition' (Rogers, 1987) or 'common sense' (Hernandez and Bennison, 2000) 


\section{Background (cont)}

- This contrasts with the major food retailers who benefit from:

- High budgets for specialised site selection departments

- Excellent data analysis capabilities and sources (e.g. loyalty cards)

- But conditions in the neighbourhood market are changing:

Unis 


\section{Tesco acquisitions}

January 2003: Purchase of 862 unit T\&S convenience stores

January 2004: Agreed offer to buy 45 convenience stores from Adminstore, located primarily within the M25;

September 2005: Purchased 21 petrol filling stations and convenience stores from rival Wm Morrison.
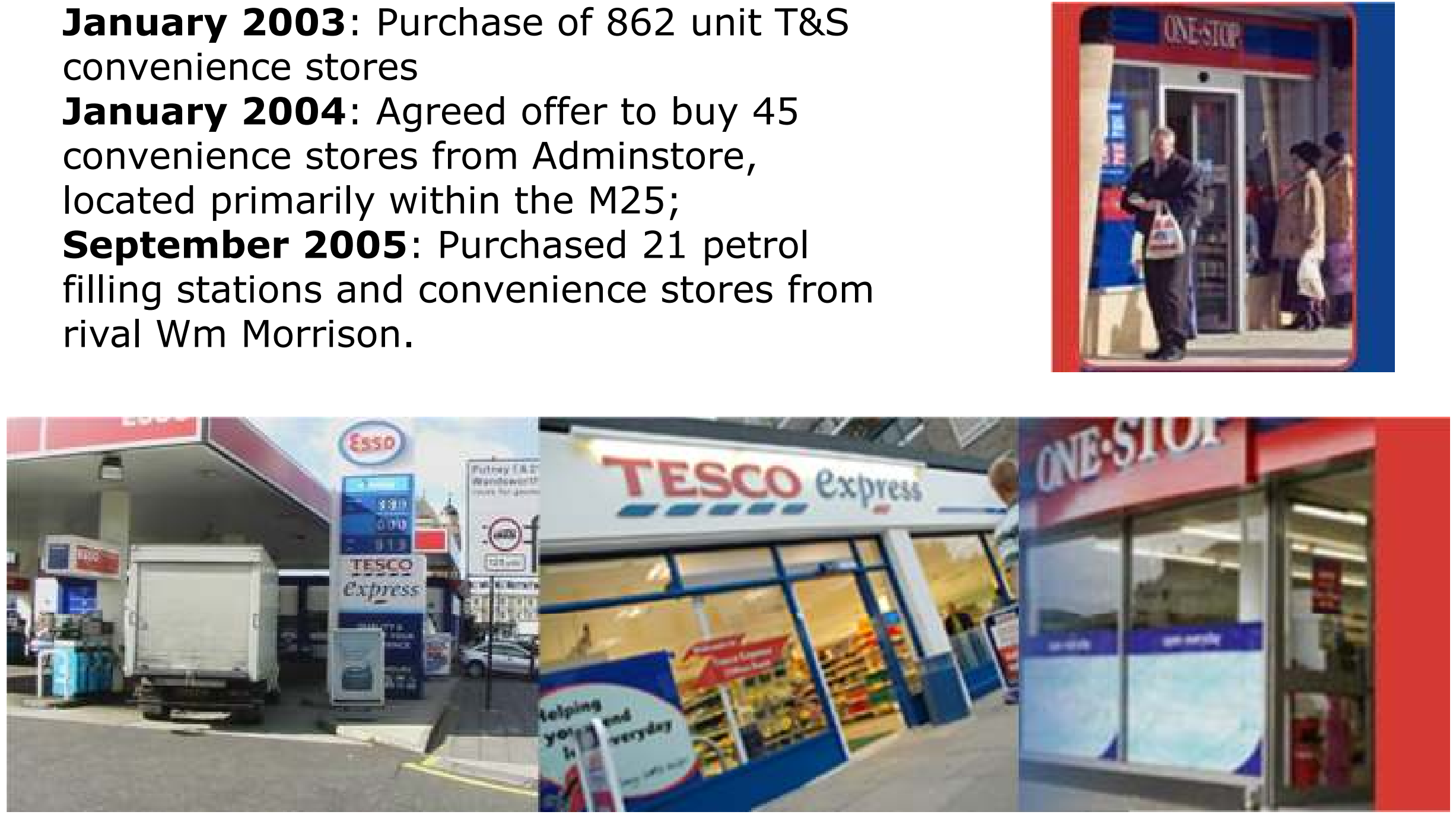


\section{Sainsburys acquisitions}

February 2004: purchase of 54 store Bells Stores;

August 2004: acquisition of the 114 strong Jacksons chain;

November 2004: purchase of 6 store JB Beaumont;

April 2005: Purchase of 5 store SL Shaw Ltd
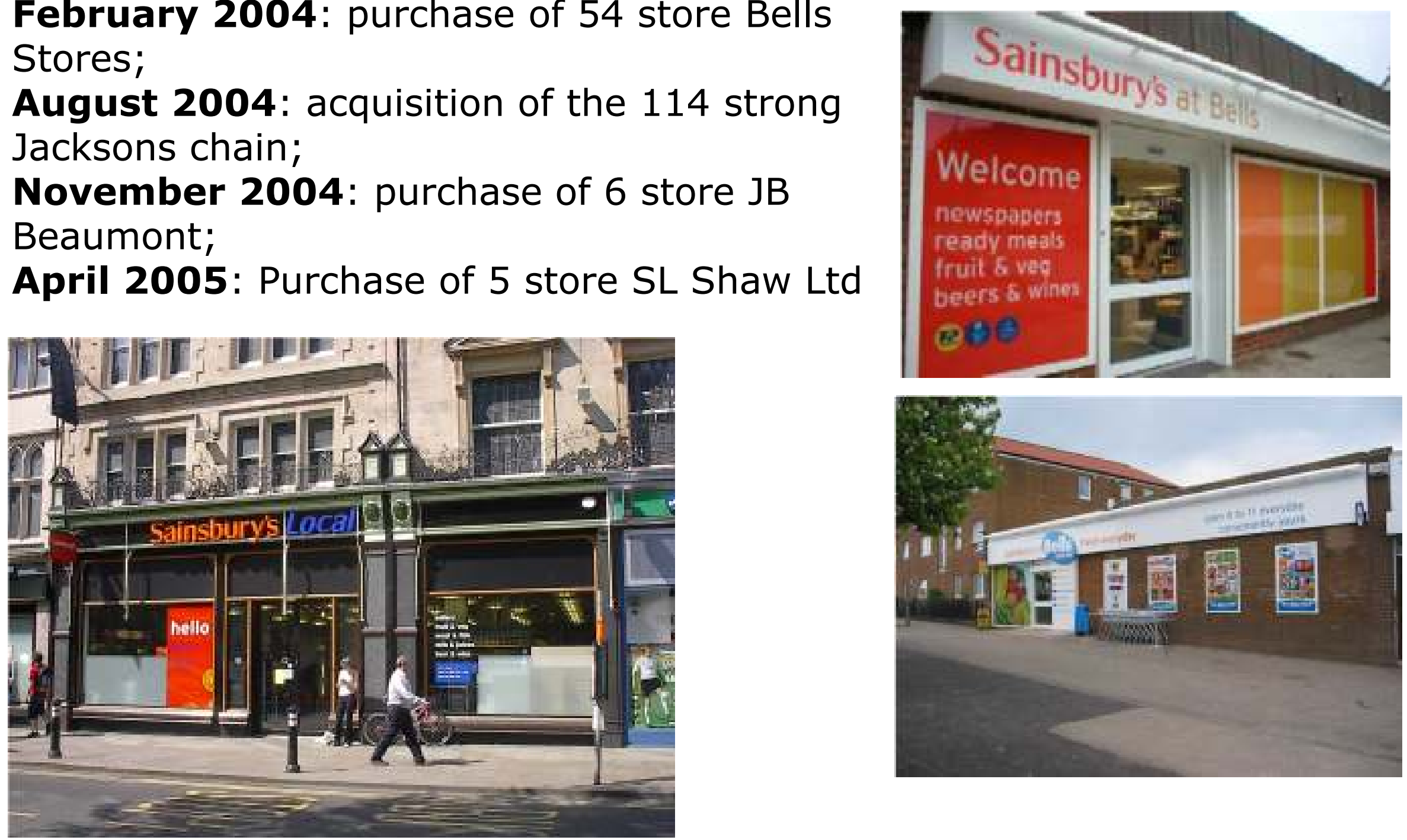


\section{Co-op acquisitions}
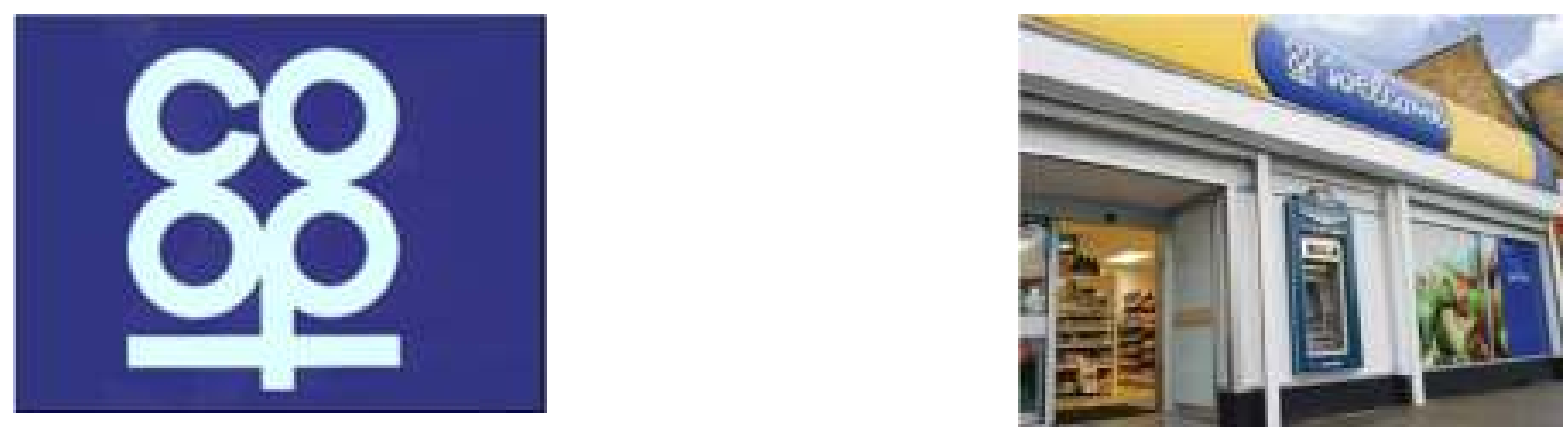

- October 2002: purchase of 600 unit Alldays chain

- July 2003: acquisition of Balfour, a chain of 121 stores

- In addition, other small store development by M\&S with the Simply Food format (though not c-store)

Unis 


\section{Approaches to new site forecasting}

- Gravity modelling via GIS systems (drivetimes, large catchments, known spend levels)

- Analogue stores approach

- Regression models

- Strategic use of loyalty card data

- Results in high levels of accuracy

- Tesco suggest $80 \%$ of new units are within $15 \%$ of forecast (Hyman and Ainsworth, 2005) 


\section{Location planning challenges of c-stores}

- Role of micro-scale considerations with c-stores:

- Despite the latter-day advances in location modelling and geographical information systems, the outcome of locational decisions ultimately rests on micro-scale considerations... Indeed, it has often been said - though perhaps not enough - that a few yards make all the difference between success and failure in retailing

(Brown, 1994, 543, emphasis in original). 


\section{Heightens the importance of the site visit}

- To paraphrase Andrew Tasker (former Head of Location Planning at Sainsburys):

- Superstore forecasting is determined by $80 \%$ inoffice analysis to $20 \%$ site visit

- Convenience store forecasting is more $80 \%$ site visit to $20 \%$ in-office study 


\section{Small scale issues become "big"}

considerations

- A concern with "small", unstandardised competition - huge variation \& lack of databases

- Micro-scheme quality - footfall, car parking, visibility, store design, adjacent services

- Customer perceptions

- The study of drivetimes less significant 


\section{Understanding customer shopping}

missions

- The frequency of shopping missions is becoming increasingly confused and difficult to model (Clarke et al., 2006; Jackson et al., 2006)

- The locally sensitive nature of the neighbourhood market necessitates a return to less technical techniques of site evaluation 


\section{Small scale data availability}

- Need to ensure rigour of data at local spatial scale:

- Local workforce information (e.g. Blue Sheep)

- Footfall data in town/city centres (e.g. CACl)

- Population (e.g. Census data)

- Population classifications (e.g. MOSAIC; Personcix and ACORN)

- Where people live in relation to where they work (Census Travel to Work Area data)

- Food expenditure (e.g. Expenditure \& Food Survey [EFS])

- Traffic flow data (e.g. Capita Symonds; Morgan Tucker Associates)

- Datasets on the location of schools, Post Offices etc (e.g. Landmark Information Group) 


\section{Supermarket v C-store forecasting}

\begin{tabular}{|c|c|}
\hline Superstores/Hypermarkets & Neighbourhood \\
\hline $\begin{array}{l}\text { Likely a large retailer - large budget for store } \\
\text { location decision. }\end{array}$ & $\begin{array}{l}\text { Likely a small retailer - minimal budget for store location } \\
\text { decision. }\end{array}$ \\
\hline Data rich. & $\begin{array}{l}\text { Data poor. } \\
\text { Poor micro-scale accuracy to data. }\end{array}$ \\
\hline $\begin{array}{l}\text { Use of geo-demographic and customer behavioural } \\
\text { surveys aids understanding of current shopping } \\
\text { patterns. }\end{array}$ & $\begin{array}{l}\text { Data on primary shopping missions largely redundant. } \\
\text { Care required using neighbourhood data as often } \\
\text { aggregated over 100-200 households. }\end{array}$ \\
\hline $\begin{array}{l}\text { Detailed understanding of customer preferences, } \\
\text { motivations and shopping patterns. }\end{array}$ & $\begin{array}{l}\text { Very limited understanding of customer preferences, } \\
\text { motivations and shopping patterns. }\end{array}$ \\
\hline Loyalty card data aids in understanding customers. & $\begin{array}{l}\text { Unlikely to have the scale or technology for loyalty card } \\
\text { introduction. } \\
\text { If using loyalty cards; penetration levels may not be high } \\
\text { enough to extract meaningful patterns. } \\
\text { Customer surveys necessary. }\end{array}$ \\
\hline Gravity model. & $\begin{array}{l}\text { Regression model at best. } \\
\text { Overwhelming emphasis on site visits. }\end{array}$ \\
\hline $\begin{array}{l}\text { Decision-making complemented by market } \\
\text { penetration analysis based on food spend } \\
\text { statistics. }\end{array}$ & $\begin{array}{l}\text { Market penetration analysis less appropriate for c-stores as } \\
\text { commonly only the "secondary shop". }\end{array}$ \\
\hline Overwhelming reliance on car borne trade. & Reliance on local residential catchment. \\
\hline Catchment analysis to $15-30$ minute "drivetime". & $\begin{array}{l}\text { Drivetime catchment analysis largely redundant. Possibly } \\
\text { resort to "walk times" depending on store size or data }\end{array}$ \\
\hline
\end{tabular}




\section{Implications??}

- ... for a small c-store operator to think more strategically about locations given the larger operator's incursion into the sector?

- We suggest a broad framework formalising location planning for a smaller retailer lacking established in-house expertise - to move beyond the use of experience and intuition as the only decision-making tools 


\section{Considering approaches...}

- Needs to be clear, not overly technical and straightforward

- Lack of operational research knowledge as:

'Experience has certainly shown that the simpler the model, its development, working and output, the greater the comprehension by retail managers and the easier the acceptance of the model' (Simkin, 1996, p 237)

- Lack of funds for expensive data sets 


\section{Approaching c-store forecasting}

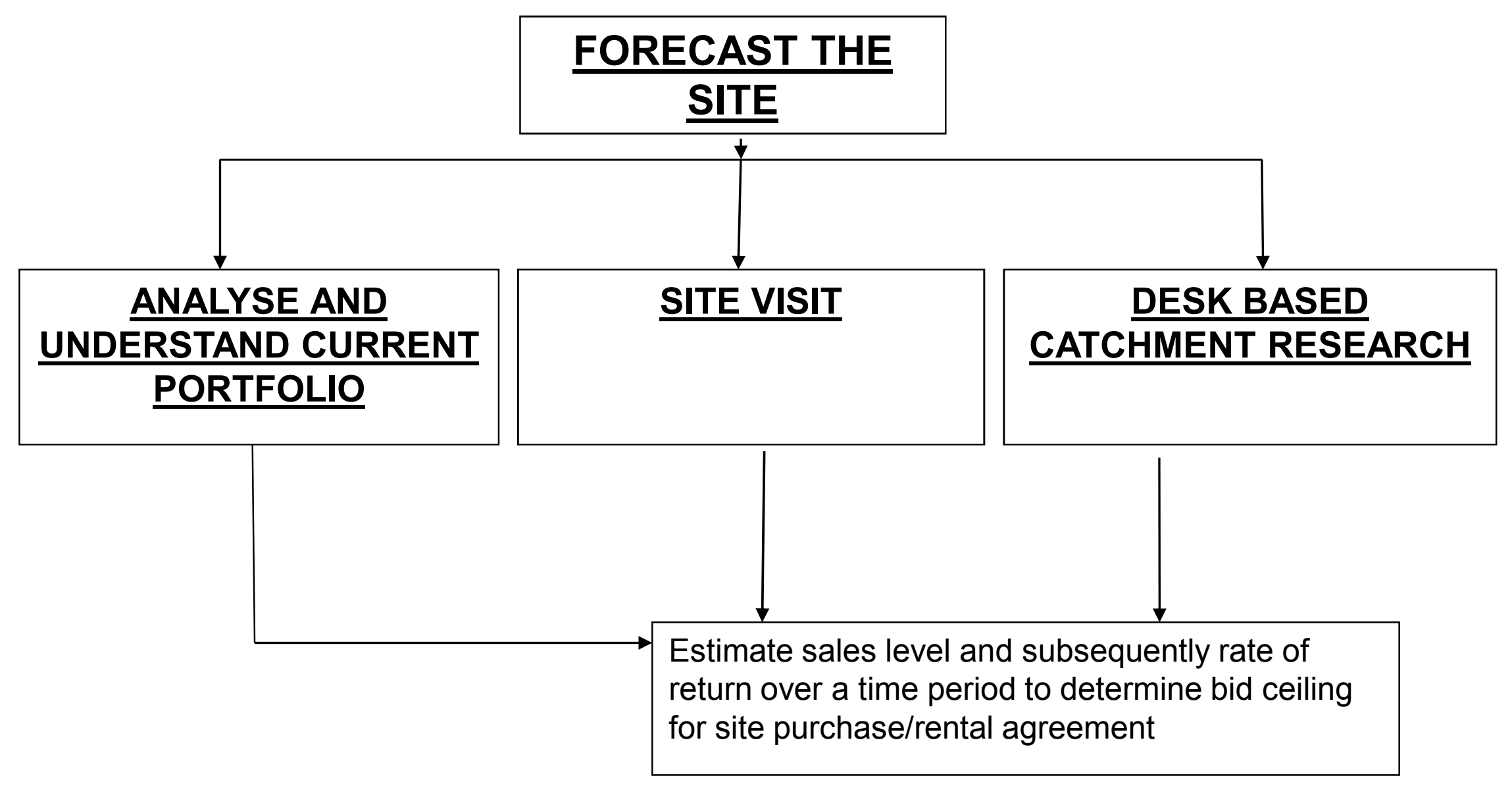

\section{Unis}




\section{Approaching c-store forecasting}

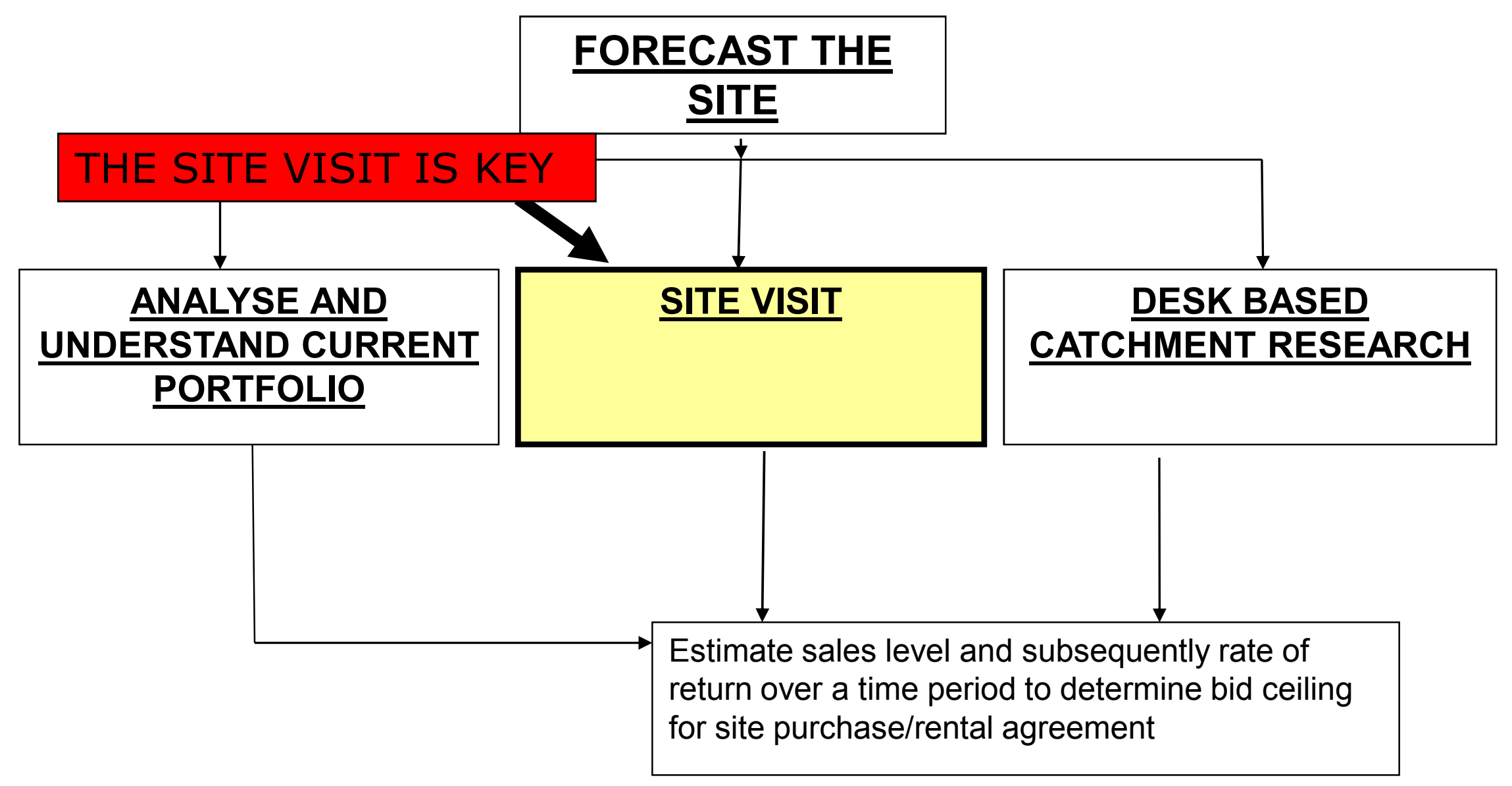

\section{Unis}




\section{Analyse And Understand Current Portfolio}

- Analyse the different "types" of location in the current portfolio (existing data and surveys)

- Different trade "drivers" for different locations and tailor turnover expectations

- Explore statistical relationships (dependent on variation in location types; analyst experience and extent of analogue set)

- Use to devise weighted checklists useful in site visit 


\section{Generic typology of convenience store locations}

\begin{tabular}{|c|c|c|c|}
\hline & Residential/Neighbourhood locations & Central locations & $\begin{array}{l}\text { High traffic flow/Petrol filling } \\
\text { station kiosk }\end{array}$ \\
\hline Location & $\begin{array}{l}\text { Local residential catchment. } \\
\text { Likely poor visibility due to location in } \\
\text { housing area. } \\
\text { Minimal "passing" traffic flow }\end{array}$ & $\begin{array}{l}\text { High street and city centres off high } \\
\text { traffic flow/footfall in central } \\
\text { locations. } \\
\text { High competition with city/town centre } \\
\text { superstores. } \\
\text { Convenience factor important resulting } \\
\text { in "pitch" becoming essential to } \\
\text { performance }\end{array}$ & $\begin{array}{l}\text { Well located on road network. } \\
\text { Not necessarily adjacent to } \\
\text { residential catchment. } \\
\text { Likely low footfall }\end{array}$ \\
\hline Catchment & $\begin{array}{l}\text { Constrained as residential and lack of } \\
\text { footfall or traffic flow. However, } \\
\text { within restricted catchment, high } \\
\text { market shares may be possible }\end{array}$ & $\begin{array}{l}\text { Extensive as located in an established } \\
\text { centre but market shares are } \\
\text { likely to be low due to } \\
\text { competition }\end{array}$ & $\begin{array}{r}\text { Larger neighbourhood catchment } \\
\text { due to strategic location on } \\
\text { the road network. Places an } \\
\text { emphasis on ability to park } \\
\text { even if not purchasing fuel }\end{array}$ \\
\hline $\begin{array}{r}\text { Customer \& } \\
\text { mission }\end{array}$ & $\begin{array}{l}\text { Families and singles on top-up, distress } \\
\text { missions. Some single } \\
\text { households" "full shop" }\end{array}$ & $\begin{array}{l}\text { Workers and shoppers often for } \\
\text { specific products (e.g. } \\
\text { lunch/snacking) but also top up }\end{array}$ & $\begin{array}{l}\text { Passing trade, top-up, distress } \\
\text { missions. Possible meal } \\
\text { solutions. }\end{array}$ \\
\hline Accessibility & $\begin{array}{l}\text { Car and foot - parking important and } \\
\text { expected }\end{array}$ & $\begin{array}{l}\text { Foot - site unlikely to have dedicated } \\
\text { car park. Reliance on town } \\
\text { centre car parks and spend from } \\
\text { workers in the area }\end{array}$ & $\begin{array}{l}\text { Car - Small car park a bonus and } \\
\text { not expected }\end{array}$ \\
\hline
\end{tabular}




\section{Site Visit}

- Use weighted checklist and contextualise any local/site specific issues that are difficult to quantify:

- pedestrian footfall \& traffic flow (if appl.)

- car parking (no. and location)

- visibility \& access from road \& pedestrian routes

- quality and location of competition

- proximity of adjacent services that may provide footfall

- type \& structure of residential catchment

- the effect of any "workers" and "lunchtime trade" \& relate to desk-based data 


\section{Desk-based catchment research}

- Less emphasis here than in superstore forecasting

- Acquire basic catchment data BUT ensure the scale of the data is appropriate for the size of formats

- Segment catchment into proportional trade areas

- Make assumptions about spend levels from different "types" of customers from the different locations

- Compare with expectations from analogous store performance for that "type" of location

- "Sense check" - assumptions of household expenditure. Does it "look" right?

Unis 


\title{
A learning process
}

- Review store performance relative to forecast after 15 weeks of trading. Analyse:

\author{
a)accuracy of forecast \\ b)possible under-performance
}

- Feedback learnings into the forecast process 


\section{Conclusion: a learning process}

- No single approach or technique is likely to provide a universal solution to forecasting convenience stores

- Manage location decision-making by incremental steps - using 'experience as a way to discover good solutions to complex problems' (Lounamaa and March, 1987, 121)

- This is wholly different to superstore retailing which is established, data intensive, deals with large catchments

Unis 